\title{
Factors affecting knowledge sharing behavior of lecturers: The case of public universities
}

\author{
Ngoc Tu Tran ${ }^{a^{*}}$
}

\begin{tabular}{l}
$\frac{{ }^{a} \text { Faculty of Business Administration }}{\text { C H R O N I C L E }}$ \\
\hline Article history: \\
Received: January 19, 2020 \\
Received in revised format: \\
March 252020 \\
Accepted: April 20, 2020 \\
Available online: \\
April 22, 2020 \\
\hline Keywords: \\
Knowledge sharing \\
Lecturer \\
Public universities
\end{tabular}

\section{A B S T R A C T}

Studying knowledge sharing behavior of lecturers at public universities in Ho Chi Minh City is an urgent issue. In the development and vastness of knowledge treasure, knowledge sharing actually becomes a way to reduce the difficulties and waste of time to learn, acquire the knowledge, thereby, helping public universities build a team of lecturers who have good knowledge and meet the job requirements for their development. Therefore, the author conducts a study to bring out the factors affecting activities of knowledge sharing behavior of lecturers at public universities in Ho Chi Minh City now. Based on the data collected, we use Cronbach's Alpha, EFA and run regression model for knowing the impact levels of each independent variable on dependent variable of the knowledge sharing behavior of lecturers. Based on the findings, some recommendations are given for improving the knowledge sharing behavior of lecturers at public universities in Ho Chi Minh City.
\end{abstract}

\section{Introduction}

Davenport and Prusak (1998) defined knowledge as a collection of experiences, values, information and insights that can help someone assess and gain new experiences and information. Knowledge is created and applied in the minds of those who have it. In an organization, knowledge is not only contained in its documents, but also in its procedures, processes, practices, and principles. Knowledge sharing is defined as the exchange of knowledge (skills, experience, and understanding) between individuals in an organization. Geraint (1998) argues that it can help employees share knowledge and experience to make projects and plans complete quickly and save cost. Knowledge management is any process of creating, acquiring, receiving, sharing, and using knowledge anywhere to enhance learning and working efficiency in organizations. It is also the process of managing and promoting an organization's knowledge (Armstrong, 2009; Sadq, 2020). Grant (1996) argued that knowledge is the most important resource the organization possesses. Gurteen (1999) argued that knowledge is an intangible product, including ideas, processes and information that increasingly shared in the global economy under various forms and is an intangible product of manufacturing economy. Knowledge is the most valuable asset and the foundation of an organization's competitive advantage (Bock et al., 2005). Therefore, people can take on new challenges and share the knowledge which they have sought, accumulated or encourage them to engage in knowledge-based activities that are particularly important. High quality lecturers mean high quality of training and universities will gain advantages and trust from learners, their families and the social community. In Vietnam, the knowledge sharing of lecturers has been of interest to researchers. However, many studies have not been done adequately and scientifically. In order to gain in-depth understanding of a teacher's knowledge sharing it is necessary to find out which factors influence their knowledge sharing which is also the topic of this study.

\section{Literature Review}

There are many researches in the world and in the country on factors affecting knowledge sharing behaviors. Al - Alawi et al. (2007), Skyrme (2008) approached in a working group and Lin (2007) approached personal knowledge-sharing behavior. Mehrabi et al. (2013) studied the relationship between organizational culture and knowledge sharing behaviors in the service 
sector. Kathiravelu et al. (2013) performed an investigation on public knowledge-sharing behavior in Malaysia. Bui (2014) assessed the knowledge sharing behavior of university lecturers in Vietnam. Canh and Dao (2016) assessed the knowledge sharing behavior of bank staff from an individual perspective. Nguyen and Pham (2018) showed that there are 6 factors affecting knowledge sharing behavior of bank employees including: Trust, communication with colleagues, information technology system, reward, team work, management interest. Based on previous studies, we summarize the factors that influence knowledge sharing behaviors as follows (see Table 1).

\section{Table 1}

Factors affecting knowledge sharing behavior in the organization

\begin{tabular}{lll}
\hline Order & Considered factors & \multicolumn{1}{c}{ Sources } \\
\hline 1 & Trust & Al-Alawi et al. (2007), Kharabsheh et al. (2012) \\
2 & Telecommunication & Al-Alawi et al. (2007), Kharabsheh et al. (2012) \\
3 & Information technology system & Al-Alawi et al. (2007), Kharabsheh et al. (2012); Akamavi \& Kimble (2005); Bock et al. (2005); \\
& Kathiravelu et al. (2013) \\
4 & Commendation rewards & Al-Alawi et al. (2007), Kharabsheh et al. (2012) \\
5 & Organization structure & Al-Alawi et al. (2007), Teimouri (2011), Javadpour and Samiei (2017) \\
6 & Technology of organization & Teimouri (2011) \\
7 & Organizational strategy & Teimouri (2011) \\
8 & Culture of the organization & Teimouri (2011), Kharabsheh et al. (2012). \\
9 & Methods of implementation & Teimouri (2011), Samadi (2018) \\
10 & Orientation of learning & Kharabsheh et al. (2012), Hassan and Din (2019) \\
11 & Mutual support & Bui (2014) \\
12 & Communication & Davenport \& Prusak (1998); Smith \& Rupp (2002); Zahidul et al. (2011) \\
13 & Leadership & Lin (2007); Zahidul et al. (2011) \\
14 & Cohesion & Lee (2001); Hislop (2003); Wuyts and Geyskens (2005); Nyaga et al. (2010); Kathiravelu et al. (2013) \\
\hline
\end{tabular}

By using the analysis of survey data obtained from lecturers of public universities in Ho Chi Minh City, we have identified and estimated the influence of the factors: (i) Trusts (NT), (ii) reward systems (KT), (ii) teamwork (LVN), (iv) Communication with colleagues (DN), (v) the scale of the support of senior management (QL), (vi) Information technology (CN) and (vii) Engagement $(\mathrm{GK})$ on knowledge sharing activities among lecturers. At the same time, the paper will analyze the strengths and weaknesses of each of these factors.

\section{Theoretical Backgrounds}

\section{Social exchange theory}

The social exchange theory is often used as the theoretical basis to explore knowledge sharing behaviors of individuals. This theory was introduced in 1958 by Homans (1958) - a sociologist, through the publication of his work "Social behavior as exchange". In particular, social behavior is the exchange of activities, tangibility or intangibility, with little or more benefits or costs, between at least two individuals (Homans, 1958). Behaviors that are rewarded or benefited under any circumstances will make individuals repeat the behavior in a similar situation. When needs of the individuals are almost completely satisfied, they will make less effort in their efforts to find them. If being rewarded or benefited, a behavior tends to repeat. If the reward is large enough, the individual is willing to spend a lot of material and mental expenses to achieve it.

\section{Social cognitive theory}

Based on the social learning theory, Bandura et al. (1986) developed it into a social cognitive theory with the assumption that factors of learning, cognition, and environment have interactive relationships with each other. This theory has the main principle that cognition is an intermediary for learning and that people can learn through observation. Based on the social learning theory, employees observe the outside social environment, and then form behaviors based on their perceptions. In particular, individual awareness depends on two factors of self-efficiency and expected results meanwhile the influence of society is based on beliefs. Therefore, employees in an organization are only willing to share knowledge when they are sure that these behaviors will create good effects for their colleagues (Bock \& Kim, 2002; Kankanhalli et al., 2005). This also demonstrates the important role of the belief factor in knowledge sharing.

\section{Research Methodology}

The research is based on qualitative and quantitative research methods as follows:

\section{Qualitative research}

In order to explore the factors affecting knowledge sharing behavior and to adjust the scales of the factors in the proposed research model, qualitative research was conducted through 2 phases. In the first one, the author studies the theoretical basis for making hypotheses and proposing research models. In the second one, the author interviewed 07 lecturers working at public universities in Ho Chi Minh City to explore the factors affecting knowledge sharing behavior and to adjust the scales of the factors in the proposed research model. Qualitative research results form the basis for building up questionnaires to collect information to carry out quantitative research. 


\section{Quantitative research}

Quantitative research is used to measure the level of factors affecting the knowledge - sharing behavior of lecturers at public universities in Ho Chi Minh City. Sample size for research is based on convenient sample including lecturers working at public universities in the city. The author uses SPSS 22.0 software to process data and analysis, testing through the following steps: Assessing reliability of scales by Cronbach Alpha test, analyzing factor exploring EFA by KMO test and making regression analysis and testing research hypotheses by F and Sig tests. In order to obtain data for the implementation of this research, the survey was conducted with 300 lecturers working at public universities in Ho Chi Minh City. Research samples were taken mainly at public universities in this city such as the University of Finance and Marketing, Open University, Saigon University, Banking University, University of Law and Economics, etc. The sample size for the research after being filtered by the author includes 285 samples, the size of this sample is consistent with study of Hair et al. (1998), processed via SPSS 22.0 .

\section{Research Model}

Inheriting the results of previous studies and by using a qualitative research approach namely interviews with selected experts, we have designed a research model as shown in Fig. 1.

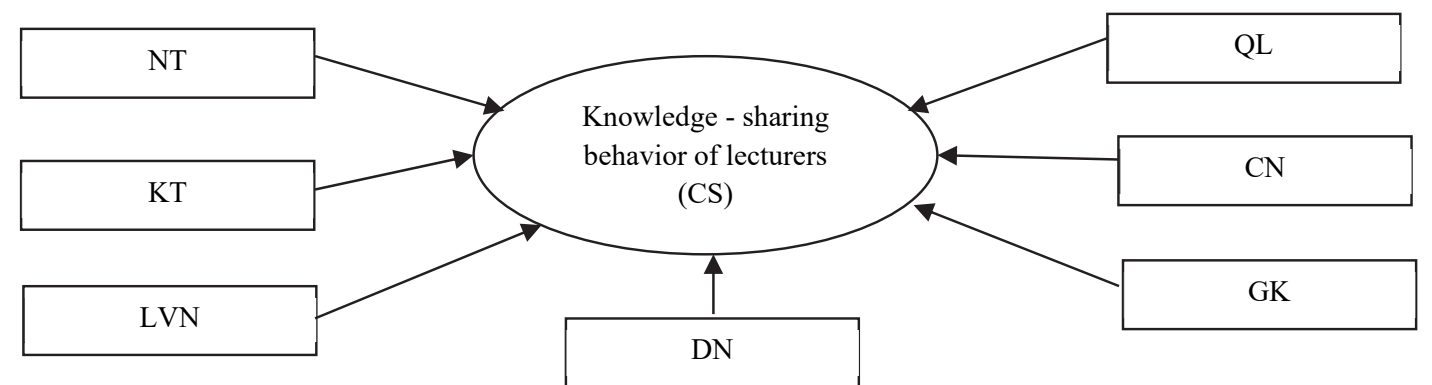

Fig. 1. Research model

Dependent variable: Knowledge - sharing behavior of lecturers (CS) are described as follows;

\begin{tabular}{ll}
\hline Code & \multicolumn{1}{c}{ Variables } \\
\hline CS1 & I am willing to share my understanding with colleagues \\
CS2 & I am willing to share my information with colleagues \\
CS3 & I am willing to share my knowledge with colleagues \\
CS4 & I work with colleagues in the same Division \\
CS5 & I collaborate with other colleagues in the division to share knowledge \\
CS6 & I access documents, information of other parts of the unit where I am working \\
CS7 & Within the Unit I am working with, employees often share knowledge with each other while working \\
\hline
\end{tabular}

Independent variable: The independent attributes are inherited by previous studies and adjusted appropriately to better suit the research context and space. The independent variables are described as follows;

\begin{tabular}{|c|c|c|}
\hline Code & Variables & Sources \\
\hline \multicolumn{2}{|c|}{ Trusts (NT) } & \multirow{7}{*}{$\begin{array}{l}\text { Hsu (2006), } \\
\text { Bock et al. (2005), } \\
\text { Blacker (1995) }\end{array}$} \\
\hline NT1 & Colleagues often consulted me at work & \\
\hline NT2 & Colleagues often appreciate my opinion & \\
\hline NT3 & Colleagues appreciate my work experience & \\
\hline NT4 & Colleagues often praised the results of my work & \\
\hline NT5 & Colleagues believe in my expertise & \\
\hline NT6 & Colleagues want to learn from my work experience & \\
\hline \multicolumn{2}{|c|}{ Reward systems (KT) } & \multirow{6}{*}{$\begin{array}{l}\text { Lin (2007), } \\
\text { Bock et al. (2005) }\end{array}$} \\
\hline KT1 & The unit I work with encourages employees to share knowledge with colleagues. & \\
\hline KT2 & Sharing knowledge with colleagues will be rewarded a lot of money by the working unit. & \\
\hline KT3 & Knowledge sharing with colleagues is evaluated by the Unit I am working on. & \\
\hline KT4 & Sharing knowledge with colleagues will be honored by the Unit I am working on. & \\
\hline KT5 & Sharing knowledge with colleagues is recognized by the Unit I am working with. & \\
\hline \multicolumn{2}{|c|}{ Teamwork (LVN) } & \multirow{7}{*}{$\begin{array}{l}\text { Alsharo (2013), Nguyen } \\
\text { et al., } 2019\end{array}$} \\
\hline LVN1 & Colleagues try to accomplish the group's goals. & \\
\hline LVN2 & Colleagues always share work in groups. & \\
\hline LVN3 & I will work more successfully if I work with my team members. & \\
\hline LVN4 & My personal experience can become great ideas when working in a team. & \\
\hline LVN5 & Team members always listen to each other's ideas. & \\
\hline LVN6 & The knowledge of each team member is combined to perform the work. & \\
\hline
\end{tabular}




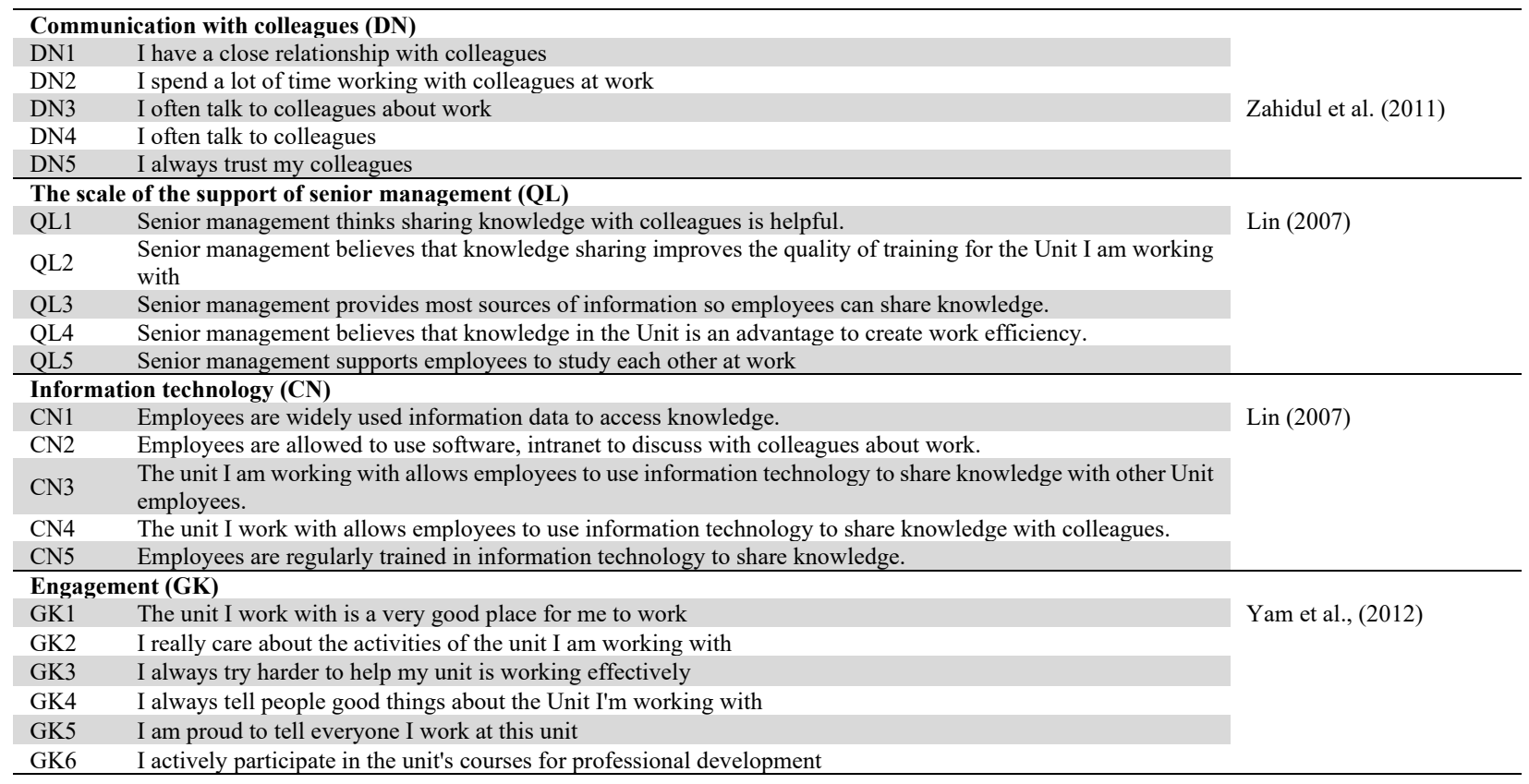

\section{Hypotheses}

H1: Trust has a positive influence on the knowledge sharing behavior of lecturers.

$\mathrm{H} 2$ : Reward systems have a positive influence on the knowledge sharing behavior of lecturers.

H3: Teamwork has a positive influence on the knowledge sharing behavior of lecturers.

$\mathrm{H} 4$ : Communication with colleagues has a positive influence on the knowledge sharing behavior of lecturers.

H5: The scale of the support of senior management has a positive influence on the knowledge sharing behavior of lecturers.

H6: Information technology has a positive influence on the knowledge sharing behavior of lecturers.

H7: Engagement has a positive influence on the knowledge sharing behavior of lecturers.

\section{Results}

\subsection{Results of Quality Scale Analysis}

By using scale analysis, it can eliminate inconsistent variables and reduce errors in the research model. Therefore, only variables which have total correlation coefficients (Corrected Item - Total Correlation) greater than 0.3 and Cronbach's Alpha coefficients equal or greater than 0.6 are accepted (Hair et al., 2009; Hoang \& Chu, 2008). Analyzing Cronbach's Alpha analysis of determinants has shown their influence on the knowledge sharing behavior of lecturers (7 determinants with 38 observed variables) and the result is presented in Table 2. Table 2 shows that, NT4 is excluded (Corrected Item - Total Correlation is $0.194<0.3$ ), GK4 is excluded (Corrected Item - Total Correlation is $0.135<0.3$ ), while the remaining, 36 Cronbach's Alpha coefficients of population are above 0.6; 30 Corrected Item - Total Correlation of observed variables are above 0.3 . So, 36 variables of research model are suitable for next analyses (Hair et al., 2006).

Table 2

Testing of scales

\begin{tabular}{|c|c|c|c|c|}
\hline & $\begin{array}{l}\text { Scale Mean if Item } \\
\text { Deleted }\end{array}$ & $\begin{array}{c}\text { Scale Variance if Item } \\
\text { Deleted }\end{array}$ & $\begin{array}{l}\text { Corrected Item-Total } \\
\text { Correlation }\end{array}$ & $\begin{array}{c}\text { Cronbach's Alpha if Item } \\
\text { Deleted }\end{array}$ \\
\hline \multicolumn{5}{|c|}{ Knowledge - sharing behavior of lecturers (CS): Cronbach's Alpha =.916 } \\
\hline CS1 & 20.11 & 9.452 & .533 & .852 \\
\hline CS2 & 20.18 & 9.166 & .627 & .839 \\
\hline CS3 & 20.12 & 9.053 & .587 & .845 \\
\hline CS4 & 20.36 & 9.979 & .593 & .846 \\
\hline CS5 & 20.30 & 8.578 & .722 & .825 \\
\hline CS6 & 20.33 & 8.357 & .696 & .829 \\
\hline CS7 & 20.30 & 9.197 & .649 & .836 \\
\hline \multicolumn{5}{|c|}{ Trusts (NT): Cronbach's Alpha $=.812$} \\
\hline NT1 & 16.26 & 6.800 & .609 & .774 \\
\hline NT2 & 16.53 & 6.856 & .626 & .771 \\
\hline NT3 & 16.52 & 7.124 & .598 & .778 \\
\hline NT4 & 16.63 & 7.952 & .194 & .875 \\
\hline NT5 & 16.33 & 6.264 & .788 & .732 \\
\hline NT6 & 16.26 & 6.586 & .763 & .742 \\
\hline
\end{tabular}


Table 2

Testing of scales (Continued)

\begin{tabular}{|c|c|c|c|c|}
\hline \multicolumn{5}{|c|}{ Reward systems (KT): Cronbach's Alpha $=.864$} \\
\hline KT1 & 14.64 & 5.315 & .623 & .851 \\
\hline KT2 & 14.58 & 5.421 & .779 & .812 \\
\hline KT3 & 14.65 & 4.939 & .623 & .850 \\
\hline KT4 & 14.67 & 4.742 & .744 & .821 \\
\hline KT5 & 14.55 & 5.953 & .664 & .841 \\
\hline \multicolumn{5}{|c|}{ Teamwork (LVN): Cronbach's Alpha $=.854$} \\
\hline LVN1 & 17.83 & 6.000 & .661 & .826 \\
\hline LVN2 & 17.91 & 6.221 & .618 & .834 \\
\hline LVN3 & 17.74 & 6.434 & .558 & .844 \\
\hline LVN4 & 17.88 & 5.828 & .673 & .824 \\
\hline LVN5 & 17.96 & 5.622 & .676 & .823 \\
\hline LVN6 & 17.97 & 5.633 & .665 & .826 \\
\hline \multicolumn{5}{|c|}{ Communicate with colleagues (DN): Cronbach's Alpha $=.848$} \\
\hline DN1 & 14.13 & 5.926 & .759 & .794 \\
\hline DN2 & 14.06 & 6.334 & .623 & .827 \\
\hline DN3 & 14.36 & 6.125 & .579 & .837 \\
\hline DN4 & 14.25 & 5.633 & .647 & .821 \\
\hline DN5 & 14.24 & 5.429 & .706 & .804 \\
\hline \multicolumn{5}{|c|}{ The scale of the support of senior management (QL): Cronbach's Alpha $=.842$} \\
\hline QL1 & 13.35 & 7.854 & .693 & .797 \\
\hline QL2 & 13.30 & 9.064 & .533 & .839 \\
\hline QL3 & 13.53 & 8.074 & .655 & .808 \\
\hline QL4 & 13.30 & 8.472 & .669 & .804 \\
\hline QL5 & 13.09 & 8.393 & .691 & .798 \\
\hline \multicolumn{5}{|c|}{ Information Technology $(\mathrm{CN})$ : Cronbach's Alpha $=.799$} \\
\hline $\mathrm{CN} 1$ & 14.47 & 5.320 & .509 & .782 \\
\hline $\mathrm{CN} 2$ & 14.52 & 4.673 & .668 & .733 \\
\hline $\mathrm{CN} 3$ & 14.62 & 4.602 & .631 & .744 \\
\hline $\mathrm{CN} 4$ & 14.67 & 4.820 & .533 & .777 \\
\hline CN5 & 14.43 & 4.915 & .572 & .763 \\
\hline \multicolumn{5}{|c|}{ Engagement (GK): Cronbach's Alpha $=.690$} \\
\hline GK1 & 18.07 & 6.554 & .504 & .624 \\
\hline GK2 & 18.01 & 6.535 & .481 & .630 \\
\hline GK3 & 18.08 & 6.035 & .550 & .603 \\
\hline GK4 & 18.11 & 5.848 & .526 & .610 \\
\hline GK5 & 18.27 & 7.735 & .135 & .738 \\
\hline GK6 & 17.98 & 7.200 & .363 & .667 \\
\hline
\end{tabular}

\subsection{Exploratory Factor Analysis}

Table 3

Exploratory Factor Analysis

\begin{tabular}{lll}
\hline Criteria & Value & Meanings \\
\hline $\begin{array}{l}\text { KMO coefficient } \\
\text { Bartlett's coefficient }\end{array}$ & 0.901 & $\begin{array}{l}\text { KMO coefficient between } 0.5-1 \text { and Sig. }=0.00 \text { showed observed variables in general are correlated with each } \\
\text { other and the EFA factor analysis is appropriate }\end{array}$ \\
$\begin{array}{l}\text { Number of factors } \\
\text { Eigenvalues }\end{array}$ & 07 & $\begin{array}{l}\text { Eigenvalues }>1 \text { and extracted variance }>50 \% \text { showed that the scale of components meet the requirements of } \\
\text { value and reliability }\end{array}$ \\
\hline Variance extracted & 63.058 & \\
\hline
\end{tabular}

KMO coefficient in the analysis $=0.901>0.6$ shows that the factor distribution results are appropriate. Bartlett's Test with a Sig coefficient of $0.000<0.05$ shows that the results of the factor analysis ensure a statistically significant level, proving that the observed variables are closely related to each other. Eigenvalues coefficient of factor 7 with $1.130>1$ indicates the convergence of the analysis stopped at factor 7. In other words, the analysis results show that 7 factors were extracted from the survey data. The factor load factor of each observed variable showed the factors $>0.5$, so the observed variables met the requirements and no observed variables were excluded. The extracted variance at $63.058 \%$ showed that 7 factors can explain $63.058 \%$ of the variability of the original survey data. This is at the appropriate significance. Thus, the results of factor analysis show that there are 7 factors extracted from the survey data to ensure the reliability of factor testing. The obtained factors will act as independent variables in the research model (Hair et al. 2009; Hoang \& Chu, 2008).

\section{Regression Model Analysis}

Determination coefficient $\mathrm{R}^{2}=0.605$ and adjusted $\mathrm{R}^{2}$ as $\mathrm{R}^{2}$ adj $=0.595$ is smaller than $\mathrm{R}^{2}$. It shows that 7 independent variables explain $59.5 \%$ of the variation of the "Knowledge - sharing behavior of lecturers" dependent variable of lecturers at public universities in Ho Chi Minh City. This proves that these 7 independent variables have a close relationship with the dependent 
variable of knowledge sharing behavior of lecturers and it is possible to regressively analyze the influence of 7 independent variables on knowledge sharing behavior (Hair et al. 2009; Hoang \& Chu, 2008).

Table 4

Correlation coefficient of the regression model

\begin{tabular}{ccccc}
\hline Model & $\mathrm{R}$ & $\mathrm{R}$ Square & Adjusted R Square & Durbin-Watson \\
\hline 1 & $.778^{\mathrm{a}}$ & 0.605 & 0.595 & 1.972 \\
\hline
\end{tabular}

In ANOVA analysis, with the value of Sig $=0.000<0.05$, ANOVA analysis has ensured a level of statistical significance, thus showing that the regression model is suitable in general. If concluding that these 7 independent variables affect knowledge sharing behaviors, it means that a reliability level of over $95 \%$ is ensured.

Table 5

ANOVA analysis results

\begin{tabular}{|c|c|c|c|c|}
\hline & Sum of Squares & Mean Square & $\mathrm{F}$ & Sig. \\
\hline Regression & 47.929 & 6.847 & 60.522 & $.000^{\mathrm{a}}$ \\
\hline Residual & 31.337 & 0.113 & & \\
\hline Total & 79.266 & & & \\
\hline
\end{tabular}

The result of regression analysis aims at determining the influence of each element in the model on the dependent variable (knowledge sharing behavior) of lecturers at the public university in Ho Chi Minh City. These levels of influence are determined through the regression coefficients. Regression analysis was in turn performed with correlation analysis, testing of regression violations and hypothesis testing. The results of correlation analysis between the independent and dependent variables show the correlation with the high correlation coefficients and the significance level. This shows that the independent variables have a good correlation with the dependent variables and this is a necessary condition for using the independent and dependent variables in regression analysis. Among the independent variables, there are also variables that the level of correlation is high but the correlation coefficient is quite low. So, in the analysis process, it is necessary to check the multi-collinear phenomenon by the method of checking the VIF coefficient of the independent variables in the model. Regression model measures factors affecting the knowledge - sharing behavior of lecturers at public universities in Ho Chi Minh City with research results as followed:

Table 6

Regression model of factors affecting knowledge sharing

\begin{tabular}{|c|c|c|c|c|}
\hline \multicolumn{4}{|c|}{ Regression coefficient } & \\
\hline & $\mathrm{B}$ & Beta & S1g. & VIF \\
\hline (Constant) & 0.053 & & 0.770 & \\
\hline Trust & 0.125 & 0.133 & 0.005 & 1.546 \\
\hline Reward systems & 0.160 & 0.187 & 0.000 & 1.863 \\
\hline Teamwork & 0.240 & 0.219 & 0.000 & 1.850 \\
\hline Communication with colleagues & 0.104 & 0.117 & 0.018 & 1.693 \\
\hline The scale of the support of senior management & 0.090 & 0.121 & 0.020 & 1.883 \\
\hline Information Technology & 0.140 & 0.143 & 0.003 & 1.558 \\
\hline Engagement & 0.117 & 0.135 & 0.009 & 1.873 \\
\hline
\end{tabular}

In the regression coefficient table, the Sig coefficient of the independent variables in the model all has significance levels less than 0.05 . This shows that the variables in the model all influence the dependent variable on the knowledge - sharing behavior of lecturers. Thus, hypotheses H1, H2, H3, H4, H5, H6 and H7 are accepted with 95\% reliability (Hair et al., 2009; Hoang \& $\mathrm{Chu}, 2008$ ). Therefore, the results of regression analysis have fully satisfied the testing requirements in the analysis, so the regression equation showing the influence level of the factors in the model is formulated as follows:

Unstandardized regression model:

$\mathrm{CS}=0.053+0.125 \mathrm{NT}+0.160 \mathrm{KT}+0.240 \mathrm{LVN}+0.104 \mathrm{DN}+0.090 \mathrm{QL}+0.140 \mathrm{CN}+0.117 \mathrm{GK}$

Standardized regression model:

$\mathrm{CS}=0.133 \mathrm{NT}+0.187 \mathrm{KT}+0.219 \mathrm{LVN}+0.117 \mathrm{DN}+0.121 \mathrm{QL}+0.143 \mathrm{CN}+0.135 \mathrm{GK}$

\section{Discussion}

Trust is a positive expectation to one's integrity, ability, honesty, and goodwill for the capacity of other colleagues in the organization. Trust plays an important role in social relationships, rather than in economic transactions (Bartol \& Srivastava, 2002). Therefore, trust will facilitate knowledge sharing, because one's willingness to share one's knowledge with others is a 
social exchange. Research of Davenport and Prusak (1998) reinforce the perception that if a company has mutual trust, implementation of knowledge sharing will be easier. Trust plays a very important role in knowledge sharing (Davenport \& Prusak, 1998). The commendation reward system is a set of necessary incentives for members in organizations to guide their behavior (Cabrera \& Bonache, 1999) or to improve effectiveness in learning (Pham \& Swierczek, 2006). Rewards of organizations can be physical benefits such as salary increases, bonuses, or non-physical benefits such as recognition of performance, appreciation or consideration of prioritized promotions. In addition, long-term rewards such as profit sharing or other options are also seen as an effective means of promoting knowledge sharing compared to other short-term incentives. For the need to promote exchange, sharing and creativity in groups of lecturers, they must work together to improve knowledge. The members of a working group must come from different units, which they usually only know about their expertise and lack the necessary knowledge of other areas. Cultural differences can also create difficulties in making teamwork. Therefore, it is essential to increase the ability and efficiency of teamwork, especially the sharing and viewpoint exchange of team members. Communication among colleagues in the organization is the basis of encouraging knowledge sharing (Smith \& Rupp, 2002). The organization encourages the knowledge sharing and knowledge come naturally into the organization to foster open discussions, enthusiastic debates and to make individuals (no matter what their position is) freely show their opinions and own viewpoints on a variety of issues (Davenport \& Prusak, 1998). By practical activities, individuals can collect information and data from many different groups, evaluate their opinions and viewpoints. Then, they can convert data and information to create new knowledge for themselves. Senior management is a team that includes the highest-level individuals of public universities, is responsible for managing and taking responsibility for their decisions in the joint activities of the public universities in Ho Chi Minh City. In the process of building knowledge - based values that public universities in Ho Chi Minh City is building, senior managers can affect lecturers (under their management) by creating and preserving the organization's positive values and beliefs (Lin, 2007). The support and attention of senior managers will affect lecturers' awareness in sharing knowledge. Information technology system includes human factors, data and processes that systematically arranged based on modern technical and technological equipment to create interaction with each other and to support daily operations, to solve problems, to make important decisions in the organization, is a collection of modern facilities and tools - mainly computers and telecommunications to effectively exploit and use the abundant information resources. Organizations often create or gather existing information into a knowledge base so that lecturers can easily share their expertise through electronic technology equipment or easily access to knowledges and experiences of others. Such knowledge connection allows companies to transfer knowledge to new lecturers, so that the information technology system will promote the reception of new knowledge and consolidate the previously-accumulated knowledge or utilize in the whole organization (Bharadwaj, 2000). Lee (2001) argues that knowledge sharing is the process of transmitting or disseminating knowledge from one person, group or organization to other. The organization always encourages knowledge and open communication between units. A high degree of cohesion will build trust from individuals and departments (Wuyts \& Geyskens, 2005). Cohesion promotes the process of communication and knowledge sharing in the organization. In addition, it is also an important signal for partners to see the willingness to communicate and exchange information and knowledge to make it easier to grasp knowledge. The study of Nyaga et al. (2010) concluded that when one person shares important knowledge to others, it is an affirmation of attachment to those people and motivating them to reshare knowledge

\section{Administrative Implications}

\section{Implication for teamwork}

Encouraging personal development: This is a skill for a team leader, a department head or a dean in the role of a leader who has the bravery and ability to encourage, motivate and facilitate team members to personally develop in his/her team. Members in the same group should help each other at work. It is necessary and ready to share and help colleagues if they face difficulties. It will create cohesion between the team members.

Creating consensus: Without teamwork skills, it is easy to cause conflicts due to contrary opinions among members. At this time, it is very important for creating a consensus in the group to work towards common interests. This is not an easy skill. To achieve the consensus of the members, besides giving opinions, it is very necessary to listen and respect the opinions of others, find the way to analyze right, wrong opinions and persuade teammates.

\section{Administrative implications of improving Trust among lecturers}

With the knowledge exchange of each department, it is also necessary to attract the participation of some experts from other departments in the public universities in Ho Chi Minh City. This not only has the effect of learning the experiences of the departments in effectively exchanging knowledge, but also helps the departments get objective suggestions in the process of knowledge sharing. Besides conducting exchanges, public universities in Ho Chi Minh City also needs to have exchange meetings and teamwork activities among lecturers such as activities of singing, and sports and entertainment. These create effective cohesion inside universities. Unions of public universities in Ho Chi Minh City also need to show a linking role in creating cohesion and solidarity among lecturers in the universities, paying attention to visiting, encouraging and understanding the difficulties of lecturers in work and life. They show the effective supports to help people feel the working environment as a second family. 
Collaborating with libraries of many domestic and foreign universities to share the endless treasure of human knowledge is necessary. Public universities in Ho Chi Minh City needs to build a forum sharing website or an online document sharing site, thereby simplifying contribution of documents as well as viewing of documents through the lecturers' accounts. Public universities can also develop more tools to work online in groups through the Google Drive and to provide lecturers with internal email systems to work online with the team anywhere, anytime. Making plans to support lecturers on technology equipment for knowledge exchange is another important issue. The support can be implemented by finance or by direct synchronous equipment at a reasonable cost, meeting the technology requirements as well as the ability of knowledge exchange and online working.

Administrative implications of raising attention and encouragement from senior managers on knowledge sharing activities

Assessing the effectiveness of knowledge sharing and regarding as one of the criteria for commendation and promotion for lecturers is one the most important issues influencing the success of knowledge sharing. Offering a variety of incentives, not only by financial rewards, but also the accumulation of points in knowledge-sharing activities. As achieving a high score, there will be various forms of rewards. Leaders of public universities in Ho Chi Minh City should formulate a regulation to evaluate the effectiveness of knowledge sharing and consider one of criteria for rewarding and promoting for lecturers.

Administrative implications of communication during the working process at public universities in Ho Chi Minh City

Training young lecturers on how to effectively and easily communicate knowledge (through instructional activities to enhance the ability to express opinions, present ideas, etc.), thereby helping them improve their ability to share knowledge.

\section{Acknowledgement}

The authors would like to thank the anonymous referees for constructive comments on earlier version of this paper.

\section{References}

Al-Alawi, A. I., Al-Marzooqi, Y. N., \& Mohammed, Y. F. (2007). Organizational culture and knowledge sharing: Critical success factors. Journal of Knowledge Management, 11 (2), 22-42. DOI: 10.1108/13673270710738898

Akamavi, N., \& Kimble, C. (2005). Knowledge Sharing and Computer Supported Collaborative Work: the role of Organisational Culture and Trust. Proceedings of 10th UKAIS Conference, 1-9.

Alsharo, M. K. (2013). Knowledge Sharing in Virtual Teams: The Impact on Trust, Collaboration, and Team Effectiveness. Doctor of Philosophy, University of Colorado.

Armstrong, M. (2009). Armstrong's Handbook of Human Resource Management Practice. $11^{\text {th }}$ ed., Kogan Page Limited, London.

Bandura, A. (1986). Social foundations of thought and action: A social cognitive theory. Englewood Cliffs, NJ: PrenticeHall, Inc.

Bartol, K. M., \& Srivastava, A. (2002). Encouraging knowledge sharing: The role of organizational reward systems. Journal of Leadship and Organisation Studies, 9(1) $64-76$.

Bharadwaj, A. S. (2000). A resource-based perspective on information technology capability and firm performance: An empirical investigation. MIS Quarterly, 24(1), 169-196.

Blacker, F. (1995). Knowledge, knowledge work and organizations: An overview and interpretation. Organization Studies, 16 (6), $1021-1046$.

Bock, G. W., \& Kim, Y. G. (2002). Breaking the myths of rewards: An exploratory study of attitudes about knowledge sharing. Information Resources Management Journal, 15(2), 14-21.

Bock, G. W., Zmud, R. W., Kim, Y. G., \& Lee, J. N. (2005). Behavioral intention formation in knowledge sharing: Examining the roles of extrinsic motivators, social - psychological forces, and organizational climate. MIS Quarterly, 29(1), 87-111.

Bui, T. T. (2014). Factors affecting knowledge sharing behaviors between lecturers in universities. Journal of Economics and Development (Vietnam), 199, 71- 79.

Cabrera, E. F., \& Bonache, J. (1999). An expert HR system for aligning organizational culture and strategy. Human Resource Planning, 22(1), 51-60.

Canh, C. H., \& Dao, V. X. (2016). Factors affecting knowledge sharing behavior of Sacombank employees. Economy \& Forecast Review (Vietnam), 23, 33-36.

Davenport, T. H., \& Prusak, L. (1998). Working Knowledge: How Organizations Manage What They Know. Harvard Business School Press. DOI: 10.1145/348772.348775

Geraint, J., (1998). Share Strength. People Management, 4(16), 44-47.

Grant, R. M. (1996). Toward a knowledge-based view of the firm. Strat Manage Journal, 17, 109-22.

Gurteen, D. (1999). Creating a knowledge sharing culture. Knowledge Management Magazine, 2(5), 1-4. 
Hair, J. F., Joseph, F. Jr., Anderson, Rolph E., Tatham, Ronald L., and Black, Wiliam C. (1998). Multivariate data analysis. $5_{\text {th }}$ ed., Prentice Hall, Upper Saddle River, NJ.

Hair, J. F., Anderson, R. E., Tatham, R. L., \& Black, W. C. (2006). Multivariate data analysis. Upper Saddle River, NJ: Prentice-Hall International Inc.

Hair, J. F., Black, W. C., Babin, B. J., \& Anderson, R. E. (2009). Multivariate Data Analysis (7th ed.). Upper Saddle River, NJ: Prentice Hall International.

Hassan, S., \& Din, B. (2019). The mediating effect of knowledge sharing among intrinsic motivation, high-performance work system and authentic leadership on university faculty members' creativity. Management Science Letters, 9(6), 887898.

Hislop, D. (2003). Linking human resource management and knowledge management via commitment. Employee Relations, 25(2), 182-202.

Hoang, T., \& Chu, N. M. N. (2008). Analyzing researched data with SPSS (2 ${ }^{\text {nd }}$ ed.). Ho Chi Minh City, Vietnam: Hong Duc Publishing House.

Homans, G. C. (1958). Social Behavior as Exchange. American Journal of Sociology, 63(6), 597-606.

Hsu, I. C. (2006). Enhancing employee tendencies to share knowledge - Case studies of nine companies in Taiwan. International Journal of Information Management, 26(4), 326-338.

Javadpour, A., \& Samiei, S. (2017). Motivation and barriers to participation in virtual knowledge-sharing communities of practice. Management Science Letters, 7(2), 81-86.

Kankanhalli, A., Tan, B. C. Y., \& Wei, K. -K. (2005). Contributing knowledge to electronic knowledge repositories: An empirical investigation. MIS Quarterly, 29(1), 113-143.

Kharabsheh, R., Magableh, I., Zuriqat, K. (2012). Factors Affecting Knowledge Sharing (KS) in Jordanian Pharmaceutical Companies. European Conference on Knowledge Management, Kidmore End: 584-XXII. Kidmore End: Academic Conferences International Limited. (Sep 2012).

Lee, J. N. (2001). The impact of knowledge sharing, organizational capability and partnership quality on IS outsourcing success. Information \& Management, 38(5), 323-335.

Lin, H. F. (2007). Knowledge sharing and firm innovation capability: An empirical study. International Journal of Manpower, 28(3/4), 315-332.

Kathiravelu, S. R., Mansor, N. N. A., \& Kenny, K. (2013). Factors Influencing Knowledge Sharing Behavior (KSB) among Employees of Public Services in Malaysia. International Journal of Academic Research in Economics and Management Sciences, 2(3), 107-119.

Mehrabi, S., Siyadat, S. \& Allameh, S. (2013). Studying the relationship between the process of knowledge Sharing and organizational agility among personnel of Agriculture- Jahad Organization in Share-Kord. International Journal of Academic Research in Business and Social Sciences, 3(5), 324-36.

Nguyen, N. D. P. \& Pham, T. S. (2018). Factors affecting knowledge sharing behavior of bank employees - Research at Joint Stock Commercial Bank for Industry and Trade of Vietnam - Lam Dong province. Industry and trade magazine (Vietnam), 14, 281-286.

Nguyen, T., Nguyen, K., \& Do, T. (2019). Knowledge sharing and innovative work behavior: The case of Vietnam. Uncertain Supply Chain Management, 7(4), 619-634.

Nyaga, G.N., Whipple, J.M., \& Lynch, D.F. (2010). Examining supply chain relationships: do buyer and supplier perspectives on collaborative relationships differ? Journal of Operations Management, 28(2), 101-114.

Pham, N. T., \& Swierczek, F. W. (2006). Facilitators of organizational learning in design. The Learning Organization, $13(2), 186-201$.

Sadq, Z., Othman, B., \& Mohammed, H. (2020). Attitudes of managers in the Iraqi Kurdistan region private banks towards the impact of knowledge management on organizational effectiveness. Management Science Letters, 10(8), 1835 1842.

Samadi, S. (2018). Theory of planned behavior and knowledge sharing among nurses in patient computer management system: The role of distributive justice. Management Science Letters, 8(5), 427-436.

Smith, A., \& Rupp, W. (2002). Communication and loyalty among knowledge workers: a resource of the firm theory view. Journal Knowl Manage, 6(3), 250-261.

Skyrme, D. J. (2008). The 3Cs of Knowledge Sharing: Culture, Co-opetition and Commitment. Main Feature, 64, 1-6.

Teimouri, M. (2011). Relationship between workplace friendship and organizational commitment. Thesis submitted to the School of graduate Studies, University Putra Malaysia.

Wuyts, S., \& Geyskens, I. (2005). The formation of buyer-supplier relationships: detailed contract drafting and close partner selection. Journal of Marketing, 69(4), 103-117.

Yam, P.T., Kent, C.B., Morin, S., Farmer, W.T., Alchini, R., Lepelletier, L., Colman, D.R., Tessier-Lavigne, M., Fournier, A.E., and Charron, F. (2012). 14-3-3 proteins regulate a cell-intrinsic switch from sonic hedgehog-mediated commissural axon attraction to repulsion after midline crossing. Neuron, 76, 735-749.

Zahidul, I. M., Hasan, I., Ahmed, S., \& Ahmed, S. M. (2011). Organizational culture and knowledge sharing: Empirical evidence from service organizations. African Journal of Business Management, 5(14), 5900-5909. 
(C) 2020 by the authors; licensee Growing Science, Canada. This is an open access article distributed under the terms and conditions of the Creative Commons Attribution (CC-BY) license (http://creativecommons.org/licenses/by/4.0/). 